\title{
Programa dos 10 pontos dos Panteras Negras (1966)'
}

Partido dos Panteras Negras

\section{Queremos liberdade. Queremos o poder para determinar o destino de nossa Comunidade Negra.}

Nós acreditamos que o povo preto não será livre até que nós sejamos capazes de determinar nosso destino.

\section{Queremos emprego para nosso povo.}

Nós acreditamos que o governo federal é responsável e obrigado a dar a cada homem emprego e renda garantida. Nós acreditamos que se o homem de negócios americano branco não nos dá emprego, então os meios de produção devem ser tomados dos homens de negócios e ser colocados na comunidade de modo que o povo da comunidade possa organizar e empregar todas as pessoas e dar-lhes um padrão elevado de vida.

\section{Precisamos acabar com a exploração do homem branco na Comunidade Negra.}

Nós acreditamos que este governo racista tem nos explorado e agora nós estamos demandando a quitação do débito de quarenta acres de terra e duas mulas. Quarenta acres e duas mulas foram prometidos 100 anos atrás em restituição pelo trabalho escravo e assassinato

1 Versão encontrada no caderno de textos virtual Panteras negras: estratégia e revolução, organizado pelo coletivo Casa da Resistência, disponível em <https:// gatopretocomunicacao.files.wordpress.com/2016/12/caderno-completo.pdf>. 
em massa do povo preto. Nós aceitaremos o pagamento em moeda corrente, que será distribuída às nossas muitas comunidades. Os Alemães estão agora reparando os Judeus em Israel pelo genocídio do povo Judeu. Os Alemães assassinaram seis milhões de Judeus. $O$ Racista Americano tomou parte no massacre de mais de vinte milhões de pessoas pretas; consequentemente, nós sentimos que esta é uma demanda modesta que nós fazemos.

\section{Nós queremos moradia, queremos um teto que seja adequa- do para abrigar seres humanos.}

Nós acreditamos que se os senhores de terra brancos não dão moradia descente para a nossa comunidade negra, então a moradia e a terra devem ser transformadas em cooperativas de maneira que nossa comunidade, com auxílio governamental, possa construir e fazer casas descentes para as pessoas.

5. Nós queremos uma educação para nosso povo que exponha a verdadeira natureza da decadente sociedade Americana. Queremos uma educação que nos mostre a verdadeira história e a nossa importância e papel na atual sociedade americana.

Nós acreditamos em um sistema educacional que dê a nossos povos um conhecimento de si mesmo. Se um homem não tiver o conhecimento de si mesmo e de sua posição na sociedade e no mundo, então tem pouca possibilidade relacionar-se com qualquer outra coisa.

\section{Nós queremos que todos os homens negros sejam isentos} do serviço militar.

Nós acreditamos que o povo preto não deve ser forçado a lutar no serviço militar para defender um governo racista que não nos protege. Nós não lutaremos e mataremos os povos de cor no mundo que, como o povo preto, estão sendo vitimados pelo governo racista branco da América. Nós nos protegeremos da força e da violência da polícia racista e das forças armadas racista, por todos os meios necessários. 
7. Nós queremos o fim imediato da brutalidade policial e assassinato do povo preto.

Nós acreditamos que nós podemos terminar a brutalidade da polícia em nossa comunidade preta organizando grupos pretos de autodefesa que são dedicados a defender nossa comunidade preta da opressão e da brutalidade racista da polícia. A segunda emenda da Constituição dos Estados Unidos dá o direito de portar armas. Nós acreditamos consequentemente que todo o povo preto deve se armar para a autodefesa.

8. Nós queremos a liberdade para todos os homens pretos mantidos em prisões e cadeias federais, estaduais e municipais.

Nós acreditamos que todas as pessoas pretas devem ser liberadas das muitas cadeias e prisões porque não receberam um julgamento justo e imparcial.

9. Nós queremos que todas as pessoas pretas quando trazidas a julgamento sejam julgadas na corte por um júri de pares do seu grupo ou por pessoas de suas comunidades pretas, como definido pela Constituição dos Estados Unidos.

Nós acreditamos que as cortes devem seguir a Constituição dos Estados Unidos de modo que as pessoas pretas recebam julgamentos justos. A $14^{a}$ emenda da Constituição dos ESTADOS UNIDOS dá a um homem o direito de ser julgado por pares de seu grupo. Um par é uma pessoa com um acúmulo econômico, social, religioso, geográfico, ambiental, histórico e racial similar. Para fazer isto a corte será forçada a selecionar um júri da comunidade preta de que o réu preto veio. Nós fomos, e estamos sendo julgados por júris todo-brancos que não têm nenhuma compreensão "do raciocínio do homem médio" da comunidade preta.

10. Nós queremos terra, pão, moradia, educação, roupas, justiça e paz. E como nosso objetivo político principal, um plebiscito supervisionado pelas Nações-Unidas a ser realizado em toda a 
colônia preta no qual só serão permitidos aos pretos, vítimas do projeto colonial, participar, com a finalidade de determinar a vontade do povo preto a respeito de seu destino nacional.

Programa de 10 pontos escrito em 15 de outubro de 1966, quando da fundação do Partido dos Panteras Negras de Autodefesa, por Huey Newton e Bobby Seale. 